\title{
WARTOŚĆ PRAKTYCZNA KLASYFIKACJI DIAGNOZ PIELĘGNIARSKICH ICNP® I NANDA W OPINII STUDENTÓW PIELEGGNIARSTWA
}

\section{THE PRACTICAL VALUE OF THE ICNP® AND NANDA CLASSIFICATIONS OF NURSING DIAGNOSES IN THE OPINIONS OF NURSING STUDENTS}

\author{
Barbara Ślusarska ${ }^{1}$, Danuta Zarzycka², Alina Deluga1, Beata Dobrowolska ${ }^{3}$ \\ ${ }^{1}$ Zakład Medycyny Rodzinnej i Pielęgniarstwa Środowiskowego \\ Uniwersytet Medyczny w Lublinie \\ ${ }^{2}$ Zakład Pielęgniarstwa Pediatrycznego \\ Uniwersytet Medyczny w Lublinie \\ ${ }^{3}$ Katedra Rozwoju Pielęgniarstwa \\ Uniwersytet Medyczny w Lublinie
}

DOI: https://doi.org/10.20883/pielpol.2017.55

\section{STRESZCZENIE}

Wprowadzenie. W Polsce od kilku lat trwają dyskusje na temat unifikacji terminologii pielęgniarskiej oraz próby wdrażania ICNP® i NANDA do praktyki klasyfikacji. Nadal jednak w literaturze brakuje wiarygodnych polskich wyników badań pozwalających na oszacowanie wartości powyższych systemów pod względem ich użyteczności praktycznej.

Cel. Przedstawienie opinii studentów pielęgniarstwa na temat wartości praktycznej klasyfikacji diagnoz pielęgniarskich ICNP® i NANDA na podstawie wyników analizy grupowej.

Materiał i metody. Badania przeprowadzono w 2016 roku wśród 88 studentów kierunku pielęgniarstwo studiów magisterskich w Lublinie. Metodą badawczą była analiza dokumentacji dydaktycznej studentów zgromadzonej podczas realizowania efektów kształcenia, dotyczącej zastosowania w praktyce systemów klasyfikacji ICNP® i NANDA oraz analiza opinii studentów na temat użyteczności praktycznej przedstawionych systemów.

Wyniki. Studenci sformułowali 345 argumentów „za i przeciw” użyteczności praktycznej analizowanych systemów klasyfikacji. Spośród 181 stwierdzeń przypisanych ICNP® 56,9\% miało desygnaty argumentacji negatywnej, a 43,1\% - pozytywnej. W grupie 164 argumentów wymienionych dla systemu NANDA aż 72,56\% miało charakter pozytywnych opinii, a 27,44\% - negatywnych.

Podsumowanie. Analiza ilościowa oraz jakościowa argumentów użyteczności praktycznej ICNP® i NANDA pozwala wnioskować o wyższej użyteczności w praktyce pielęgniarskiej systemu NANDA.

SŁOWA KLUCZOWE: taksonomie, ICNP®, NANDA, pielęgniarstwo.

\begin{abstract}
Introduction. In Poland for a couple of years the unification of nursing terminology and attempts of the ICNPß and NANDA classifications implementation have been discussed. Up to this moment, however, in the Polish professional literature there have been no reliable findings enabling the assessment of the practical usefulness of the abovementioned systems.

Aim. The presentation of nursing students' opinions on the practical value of the ICNP ${ }^{\circledR}$ and the NANDA classifications of nursing diagnoses based on the group analysis.

Material and methods. The research was conducted in 2016 among 88 Master's-Degree students in the field of nursing in Lublin. The research method was an analysis of students' documentation reflecting the use of ICNP ${ }^{\circledR}$ and NANDA classification systems for the description of nursing practice based on randomly chosen case studies, and the opinion of the students on the practical use of the abovementioned systems.

Results. The students formulated 345 'for and against' arguments of the practical use of the analysed classification systems, including 181 arguments concerning the ICNP® classification and 164 arguments concerning the NANDA system. $56.9 \%$ of 181 statements on the ICNP® constituted negative arguments and $43.1 \%$ were positive. In the group of 164 arguments on the NANDA system as many as $72.56 \%$ were positive opinions and $27.44 \%$ were negative.

Conclusion. Analysis of quantitative and qualitative arguments on the practical use of the ICNP® and NANDA leads to the conclusion that the NANDA system has greater usefulness in nursing practice.
\end{abstract}

KEYWORDS: taxonomies, ICNP®, NANDA, nursing. 


\section{Wprowadzenie}

W Polsce od kilku lat trwają dyskusje w kręgach profesjonalistów pielęgniarstwa na temat unifikacji terminologii pielęgniarskiej pomiędzy różnymi systemami klasyfikacyjnymi oraz próby wdrożenia tych systemów do praktyki celem uzyskania poprawy jakości opieki pielęgniarskiej i jej transparentności względem już istniejących systemów informatycznych w opiece zdrowotnej [1-4]. Należy zauważyć, że bez znormalizowanej nomenklatury pielęgniarstwo staje się niewidoczne w systemie opieki zdrowotnej, a trudne do oszacowania nakłady i wyniki opieki pielęgniarskiej przyczyniają się do stagnacji zarówno w zakresie rozwoju profesjonalnej wiedzy, jak i swoistych interwencji pielęgniarskich, opartych na wiarygodnych dowodach naukowych [5]. Amerykańskie Towarzystwo Pielęgniarskie (ANA) uznato do tej pory 12 systemów klasyfikacji terminologii pielęgniarstwa za użyteczne narzędzia przeznaczone do wspierania praktyki pielęgniarskiej [6, 7]. Taksonomie i systemy klasyfikacyjne odpowiadają za uporządkowanie wiedzy w taki sposób, że elementy obszaru tematycznego są zorganizowane $w$ grupy lub podstawowe klasy ze względu na ich podobieństwa [8]. Na świecie istnieją różne systemy klasyfikacji pielęgniarskich, które pretendują do miana znormalizowanych słowników. Do najstarszych, a zarazem najbardziej powszechnych i zbadanych taksonomii diagnoz pielęgniarskich należy klasyfikacja NANDA (North American Nursing Diagnosis Association), opracowana przez Północnoamerykańskie Towarzystwo Diagnozowania w Pielęgniarstwie [9]. W Polsce głównym źródłem wiedzy o tym systemie klasyfikacyjnym jest podręcznik diagnoz pielęgniarskich, wydany w 2011 roku pod redakcją naukową D. Zarzyckiej i B. Ślusarskiej [10]. W roku 2014 w Lublinie odbyło się I Forum Dyskusyjne Pielęgniarstwa pt. „Diagnozowanie stanu pacjenta w praktyce pielęgniarskiej”. W dyskusji poświęconej różnym aspektom klasyfikacji ICNP $\circledast$ i NANDA uczestniczyło ponad 200 osób. Podczas spotkania podjęto próbę wymiany poglądów na temat wartości praktycznej pielęgniarskich systemów klasyfikacji dla pielęgniarstwa polskiego [11]. Pojawiły się także pierwsze publikacje naukowe pokazujące możliwości wykorzystania systemu klasyfikacji NANDA w wybranej grupie pacjentów [12] oraz prace poglądowe na temat diagnozy pielęgniarskiej $w$ koncepcji NANDA [13].

W Europie stosunkowo rozpowszechniona jest wiedza na temat Międzynarodowej klasyfikacji praktyki pielęgniarskiej zwanej ICNP® (International Classification for Nursing Practice) [14]. Dzięki staraniom Polskiego Towarzystwa Pielęgniarskiego w 2009 roku przetłumaczono na język polski katalog ICNP® wersja 1.0. [15]. Ważnym źródłem wiedzy o ICNP® w Polsce są liczne publikacje, w których przedstawiono dokładny opis i praktyczne zastosowanie tej taksonomii [16-28].

Celem pracy jest przedstawienie opinii studentów pielęgniarstwa na temat wartości praktycznej systemów klasyfikacji diagnoz pielęgniarskich ICNP $\AA$ wersja 1.0 i NANDA na podstawie wyników analizy grupowej.

\section{Materiał i metody}

Badania przeprowadzono wśród 88 studentów kierunku pielęgniarstwo studiów magisterskich na Wydziale Nauk o Zdrowiu w Lublinie i w Wyższej Szkole Biznesu i Przedsiębiorczości w Ostrowcu Świętokrzyskim. Metodą badawczą była analiza dokumentacji dydaktycznej studentów zgromadzonej podczas realizowania efektów kształcenia, dotyczącej zastosowania w praktyce systemów klasyfikacji ICNP® i NANDA. Badania przeprowadzono w ciągu 3 miesięcy (od marca do maja) 2016 roku. Studenci byli po cyklu zajęć dydaktycznych (wykłady i seminaria - 30 godzin) z systemów klasyfikacyjnych w pielęgniarstwie. Młodzież pracowała w zespołach 2-3-osobowych, dokonując wyboru diagnoz pielęgniarskich, interwencji i wyników opieki według ICNP $\AA^{\circ}$ oraz systemu NANDA dla losowo wybranych 32 pacjentów z 7 oddziałów (interny, chirurgii, pediatrii, neurologii, onkologii, geriatrii, psychiatrii). Studenci prowadzili badanie w oparciu o metodę analizy przypadków. W podsumowaniu pracy nad możliwościami użyteczności klasyfikacji NANDA i ICNP® dla praktyki opieki pielęgniarskiej poszczególne zespoły musiały opracować zestaw argumentów „za i przeciw”. Dla pełniejszego zobrazowania uzyskanego materiału wartości analizowanych parametrów przedstawiono w postaci liczbowej i procentowej oraz dokonano analizy jakościowej. Zgromadzone „argumenty” pogrupowano w cztery kategorie, tj. układ treści ( $w$ katalogu ICNP® i NANDA), diagnozy (trafność, sposób formułowania), interwencje (trafność wyboru), użyteczność (dla środowiska pielęgniarskiego).

\section{Wyniki}

Studenci sformułowali ogółem 345 argumentów „za i przeciw" użyteczności praktycznej analizowanych systemów klasyfikacji, w tym 181 dotyczyło ICNP®, a 164 dotyczyły systemu NANDA. Spośród 181 stwierdzeń przypisanych ICNP® $103(56,9 \%)$ miały desygnaty argumentacji negatywnej, a pozostałe $78(43,1 \%)$ - pozytywnej. W grupie 164 argumentów wymienionych dla systemu NANDA aż 119 (72,56\%) miało charakter pozytywnych opinii, a $45(27,44 \%)$ - negatywnych.

Za główny argument pozytywny przemawiający za wprowadzeniem taksonomii NANDA badani uznali przede wszystkim praktyczny podział treści w podręczniku NANDA, na zagadnienia geriatryczne, pediatryczne, wielokulturowe i opieki domowej. Podkreślili, że ję- 
zyk formułowania diagnoz jest czytelny, jednoznaczny i dostosowany do celów praktycznych, a interwencje pielęgniarskie są sprawdzone i oparte na dowodach naukowych. Stwierdzili, że prezentacja zamierzonych do osiągnięcia wyników opieki oraz różnorodność proponowanych interwencji uczy pielęgniarki krytycznego myślenia i daje im możliwość doskonalenia zawodowego i uzupełnienia wiedzy (Tabela 1).

Tabela 1. Argumenty pozytywne przemawiające za wartością praktyczną systemu klasyfikacji NANDA

Table 1. Arguments in favor of the practical value of the NANDA classification

\begin{tabular}{|c|c|}
\hline Kategoria/Category & Wypowiedzi studentów/Students' opinions \\
\hline $\begin{array}{l}\text { Układ } \\
\text { Conter }\end{array}$ & $\begin{array}{c}\text { - logiczny i zrozumiały/logical and understandable } \\
\text { - zawarte treści pozwalają stworzyć profesjonalny plan } \\
\text { opieki oraz dostrzec indywidualną sytuację pacjenta/ } \\
\text { the content allows to a create professional care plan } \\
\text { and recognize the individual situation of the patient } \\
\text { - materiał stanowi swoiste dla praktyki pielegniarskiej } \\
\text { uniwersalne źródło wiedzy/the material is a specific } \\
\text { universal source of knowledge for nurses } \\
\text { - zawiera podział na różne zagadnienia (geriatryczne, } \\
\text { pediatryczne, wielokulturowe, opieki domowej)/it } \\
\text { includes a classification into various issues (geriatric, } \\
\text { paediatric, multicultural, home care) }\end{array}$ \\
\hline $\begin{array}{c}\text { Diagnozy } \\
\text { pielęgniarskie/Nursing } \\
\text { diagnoses }\end{array}$ & $\begin{array}{l}\text { - język i sposób prezentacji diagnoz jest prosty, jasny } \\
\text { i dostosowany do celów praktycznych/language } \\
\text { and presentation of diagnoses is simple, clear and } \\
\text { adapted to practical purposes } \\
\text { - jednoznaczność w interpretacji diagnoz/unambigu- } \\
\text { ous interpretation of diagnoses }\end{array}$ \\
\hline $\begin{array}{l}\text { Interwencje pielęgniar- } \\
\text { skie/Nursing interven- } \\
\text { tions }\end{array}$ & $\begin{array}{l}\text { - dostosowane do różnych grup pacjentów/adapted } \\
\text { to different types of patients } \\
\text { - sprawdzone i oparte na dowodach naukowych, co } \\
\text { zapewnia bezpieczeństwo zarówno pacjentowi, jak } \\
\text { i pielęgniarce (nie zostanie posądzona o nieetyczne } \\
\text { eksperymentowanie na pacjentach)/tested and based } \\
\text { on scientific evidence which ensures the safety of the } \\
\text { patient and the nurse (it prevents the nurse from being } \\
\text { accused of unethical experimentation on patients) }\end{array}$ \\
\hline $\begin{array}{c}\text { Użyteczność } \\
\text { praktyczna/Practical } \\
\text { usability }\end{array}$ & $\begin{array}{l}\text { • dokładne opisy przewidujące różne warianty in- } \\
\text { terwencji w tej samej sytuacji stwarzają możliwość } \\
\text { przygotowania pielegniarki np. w zakresie sprzętu, } \\
\text { jaki powinna zabrać ze sobą do pacjenta/accurate } \\
\text { descriptions of various options of interventions in } \\
\text { the same situation provide an opportunity to prepare } \\
\text { nurses e.g. in terms of equipment which should be } \\
\text { brought to the patient } \\
\text { - pielęgniarka otrzymuje podpowiedzi gotowych } \\
\text { rozwiązań, z których może korzystać, pamiętając } \\
\text { o indywidualnym podejściu do każdego pacjenta/the } \\
\text { nurse receives suggestions of ready solutions that } \\
\text { can be used keeping in mind the individual approach } \\
\text { to each patient } \\
\text { - różnorodność proponowanych interwencji zwiększa } \\
\text { możliwość doskonalenia zawodowego pielęgniarek } \\
\text { i uzupełnienia wiedzy/diversity of the intervention } \\
\text { proposed increases the possibility of professional } \\
\text { training of nurses and developing their knowledge } \\
\text { • NANDA uczy pielegniarki krytycznego myślenia/ } \\
\text { NANDA classification teaches nurses critical thinking }\end{array}$ \\
\hline
\end{tabular}

Źródło: badania własne

Source: author's own materials
Do argumentów pozytywnych odnoszących się do taksonomii ICNP® wersja 1.0 studenci zaliczyli budowę klasyfikacji wg modelu 7-osiowego, łatwość tworzenia fraz, systematyzację haseł i standaryzację języka pielęgniarskiego. Zauważyli, że zasady tworzenia diagnoz i interwencji są proste i nie wymagają długiego nakładu czasu. Stwierdzili, że ICNP® stanowi mapę wiedzy dla pielęgniarek, umożliwia dodawanie nowych terminów, pozwala na skuteczniejszy podział zadań oraz wpływa na szybsze rozpowszechnienie osiągniętych wyników (Tabela 2).

Tabela 2. Argumenty pozytywne przemawiające za wartością praktyczną systemu klasyfikacji ICNP®

Table 2. Arguments in favor for practical value of the ICNP® classification

\begin{tabular}{|c|c|}
\hline Category & Wypowiedzi studentów/Students' opinions \\
\hline $\begin{array}{l}\text { Układ treści/ } \\
\text { Content layout }\end{array}$ & $\begin{array}{c}\text { - przejrzysty, nie wymaga obszernego opisywania } \\
\text { (krótka forma)/clear, does not require extensive } \\
\text { description (short form) } \\
\text { - ułatwia szybkie tworzenie fraz/facilitates fast } \\
\text { creation of phrases } \\
\text { - zawiera usystematyzowane hasła zawarte w sied- } \\
\text { miu osiach/contains systematized terms included in } \\
\text { the seven axes } \\
\text { - podaje standaryzowane słownictwo, jakim mogą } \\
\text { posługiwać się pielęgniarki/provides standardized } \\
\text { vocabulary which can be used by nurses }\end{array}$ \\
\hline $\begin{array}{l}\text { Diagnozy pielęgnia } \\
\text { Nursing diagnos }\end{array}$ & $\begin{array}{c}\text { - są proste do utworzenia i nie wymagają długiego } \\
\text { czasu/they are simple to create and do not require } \\
\text { a long time }\end{array}$ \\
\hline $\begin{array}{l}\text { Interwencje pielęgniarskie/ } \\
\text { Nursing interventions }\end{array}$ & $\begin{array}{l}\text { • nie wymagają tworzenia zdań, tylko polegają na } \\
\text { doborze wyrazów z odpowiednich osi/they do not } \\
\text { require creation of sentences only depend on the } \\
\text { selection of words from the appropriate axis } \\
\text { • są zwięzłe, czytelne, jednakowo zrozumiałe dla } \\
\text { wszystkich/they are concise, clear, equally under- } \\
\text { stood by all } \\
\text { • ułożenie klasyfikacji działań pielęgniarskich } \\
\text { w tabele hierarchiczne reprezentujące osie jest } \\
\text { bardzo skutecznym zabiegiem powiększającym } \\
\text { pojemność informacyjną/classification of nursing } \\
\text { interventions in the hierarchical tables representing } \\
\text { the axes is a very effective procedure magnifying } \\
\text { information capacity }\end{array}$ \\
\hline $\begin{array}{l}\text { Użyteczność praktyczna/ } \\
\text { Practical usability }\end{array}$ & $\begin{array}{l}\text { • pozwala na skuteczniejszy podział zadań, lepsze } \\
\text { nadzorowanie prowadzonych prac oraz na szybsze } \\
\text { rozpowszechnianie osiągniętych wyników/allows for } \\
\text { more efficient task allocation and better monitoring } \\
\text { of the work and faster dissemination of the results } \\
\text { achieved } \\
\text { • jest czytelnym przedstawieniem interpretacji } \\
\text { danego pojęcia, rozpoznawalnym w środowisku } \\
\text { pielęgniarskim i mapą wiedzy dla pielęgniarek/there } \\
\text { is a clear representation of the concept interpreta- } \\
\text { tion, recognizable in the nursing environment and } \\
\text { the map of knowledge for nurses } \\
\text { - umożliwia dodawanie nowych terminów/allows to } \\
\text { add new terms }\end{array}$ \\
\hline
\end{tabular}

Źródło: badania własne

Source: author's own materials 
W argumentacji negatywnej w odniesieniu do taksonomii NANDA studenci zwrócili uwagę na pracochłonność tworzenia diagnoz i interwencji ze względu na brak dostępu do elektronicznej wersji klasyfikacji. Stwierdzili, że brakuje propozycji interwencji dla pacjentów psychiatrycznych oraz synonimów i wyrazów bliskoznacznych dla poszczególnych haseł (Tabela 3).

Tabela 3. Argumenty negatywne odnośnie wartości praktycznej systemu klasyfikacji NANDA

Table 3. Arguments against the practical value of the NANDA classification

\begin{tabular}{|c|c|}
\hline Kategoria/Category & Wypowiedzi studentów/Student's opinions \\
\hline $\begin{array}{l}\text { Układ treści/ } \\
\text { Content layout }\end{array}$ & $\begin{array}{c}\text { - długi czas tworzenia diagnoz, pracochłonność } \\
\text { (ze względu na książkową wersję taksonomii)/it } \\
\text { takes a long time to make diagnoses, laborious } \\
\text { (due to a book version of the taxonomy) } \\
\text { - brak dostępności systemu diagnoz w formie } \\
\text { elektronicznej/lack of the system diagnoses } \\
\text { availability in the electronic form }\end{array}$ \\
\hline $\begin{array}{l}\text { Diagnozy pielęgniarskie/ } \\
\text { Nursing diagnoses }\end{array}$ & $\begin{array}{l}\text { • brak synonimów i wyrazów bliskoznacznych } \\
\text { dla poszczególnych haseł/lack of synonyms, and } \\
\text { thesaurus for an individual term } \\
\text { - trudności w odnalezieniu odpowiedniej diagno- } \\
\text { zy (synonimy, np. duszność pod sformułowaniem } \\
\rightarrow \text { upośledzona wymiana gazowa)/difficulties in } \\
\text { finding the appropriate diagnosis (synonyms e.g. } \\
\text { dyspnoea is formulated under } \rightarrow \text { impaired gas } \\
\text { exchange) } \\
\text { - niektóre pojęcia są trudne do wyszukania bądź } \\
\text { w ogóle nieuwzględnione w klasyfikacji/some } \\
\text { terms are difficult to find or even not included in } \\
\text { the classification } \\
\text { - ograniczona liczba diagnoz pielęgniarskich (235)/ } \\
\text { a limited number of nursing diagnoses (235) }\end{array}$ \\
\hline $\begin{array}{l}\text { Interwencje pielęgniarskie/ } \\
\text { Nursing interventions }\end{array}$ & $\begin{array}{c}\text { • przedstawione są w formie zbyt obszernych } \\
\text { opisów/they are presented in the form of too } \\
\text { extensive descriptions } \\
\text { • brakuje propozycji interwencji dla pacjentów } \\
\text { psychiatrycznych/lack of proposals of interven- } \\
\text { tions for psychiatric patients }\end{array}$ \\
\hline $\begin{array}{l}\text { Użyteczność praktyczna/ } \\
\text { Practical usability }\end{array}$ & $\begin{array}{c}\text { - niska, ze względu na brak dostępności podręcz- } \\
\text { nika NANDA w formie elektronicznej/low, due to } \\
\text { the lack of availability of the NANDA textbook in } \\
\text { the electronic form }\end{array}$ \\
\hline
\end{tabular}

Źródło: badania własne

Source: author's own materials

W argumentacji „przeciw” ICNP® większość studentów podkreśliła, że korzystanie z katalogu jest utrudnione przez brak alfabetycznego ułożenia haseł, żmudny sposób ich wyszukiwania oraz brak dostępu do jednolitej wersji elektronicznej klasyfikacji. Badani zauważyli, że hasłowy sposób formułowania diagnoz i interwencji nie zawsze tworzy logiczną całość i może skutkować błędami w interpretacji. Uznali oni, że tworzone diagnozy nie odzwierciedlają wyników opieki, co ich zdaniem może utrudnić pielęgniarce ułożenie planu i dobieranie właściwych interwencji (Tabela 4).
Tabela 4. Argumenty negatywne odnośnie wartości praktycznej systemu klasyfikacji ICNP®

Table 4. Arguments against the practical value of the ICNP® classification

\begin{tabular}{|c|c|}
\hline Kategoria/Category & Wypowiedzi studentów/Students' opinions \\
\hline $\begin{array}{l}\text { Układ treści/ } \\
\text { Content layout }\end{array}$ & $\begin{array}{c}\text { - trudny i żmudny sposób wyszukiwania/difficult } \\
\text { and arduous way to search } \\
\text { • brak szczegółowości treści w poszczególnych } \\
\text { osiach/lack of a detailed content of individual axes } \\
\text { • korzystanie z książki ICNP jest utrudnione przez } \\
\text { brak alfabetycznego ułożenia poszczególnych } \\
\text { zagadnień/use of the ICNP book is complicated } \\
\text { due to the lack of an alphabetical arrangement of } \\
\text { individual issues } \\
\text { • części osi pokrywają się, przez co uzyskiwane } \\
\text { zdania tracą jednoznaczność, może to skutkować } \\
\text { redundancją zapisu/parts of axes overlap and } \\
\text { thus the resulting sentence loses its clarity, this } \\
\text { may result in redundancy of the statement }\end{array}$ \\
\hline $\begin{array}{c}\text { Diagnozy pielęgniarskie/ } \\
\text { Nursing diagnoses }\end{array}$ & $\begin{array}{c}\text { • często „zabawy w skojarzenia”, aby odnaleźć } \\
\text { odpowiedni termin w klasyfikacjiloften 'connota- } \\
\text { tions games' in order to find an appropriate term } \\
\text { in the classification } \\
\text { • formułowane „hasłowo” mogą przyczynić się } \\
\text { do błędów w interpretacji (niejednolite brzmienie } \\
\text { diagnoz)/formulated as the 'sum of slogans' which } \\
\text { can contribute to errors in interpreting (the patchy } \\
\text { wording of diagnoses) } \\
\text { • nie można w nich odnaleźć sprecyzowanych } \\
\text { wyników, co utrudnia ułożenie planu opieki/it is } \\
\text { difficult to find precisely formulated results which } \\
\text { makes it difficult to plan nursing care } \\
\text { - nie można precyzyjnie ułożyć diagnozy, brakuje } \\
\text { pojęć do tworzenia diagnoz, w tym psychiatrycz- } \\
\text { nych/you cannot precisely arrange the diagnosis, } \\
\text { there are missing concepts to create diagnoses, } \\
\text { including psychiatric ones } \\
\text { • problem ze zrozumieniem sensu diagnozy przez } \\
\text { osoby, które nie posługują się danym systemem } \\
\text { klasyfikacji/difficulty with understanding the } \\
\text { meaning of the diagnosis by people who do not } \\
\text { use the classification system }\end{array}$ \\
\hline
\end{tabular}

- tworzą ciąg wyrazów, których czasami wręcz nie da się połączyć w logiczny sposób, przez to pielęgniarka nieznająca opisu przypadku (pacjenta) może odczytać w niepoprawny sposób utworzone diagnozy i nietrafnie dobrać interwencje dla pacjenta/create a sequence of words which sometimes cannot be connected in a logical way, therefore a nurse who does not have the description of the case (patient) can understands incorrectly established diagnoses and incorrectly select interventions for the patient

Interwencje pielęgniarskie Nursing interventions

konkretnych działań możliwych do bezpośredniego wdrożenia/lack of specific actions ready to direct implementation

- z obliczeń wynika, że wszystkich zdań, jakie można ułożyć za pomocą obecnej postaci klasyfikacji, jest około tryliona, co oznacza, że tylko znikoma ich część ma odbicie w rzeczywistości/ calculations show that all sentences which can be created with the use of the classification is about one trillion, which means that only insignificant part of them is reflected in reality 


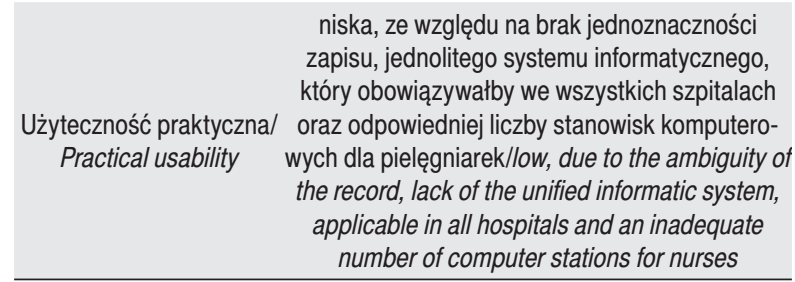

Źródło: badania własne

Source: author's own materials

\section{Dyskusja}

Polskie doświadczenia użycia systemów klasyfikacji ICNP® i NANDA w praktyce pielęgniarskiej odnośnie formułowania diagnoz, interwencji i wyników opieki są dotychczas niewielkie. W ostatnich latach pojawiło się wiele rodzimych publikacji ukazujących przykłady zastosowania ICNP® w różnych stanach chorobowych pacjentów, m.in.: w grupie chorych operowanych z powodu przepukliny pachwinowej [16], pacjentów Oddziału Intensywnej Opieki Medycznej [17], chorych z oparzeniem termicznym [18], chorych będących w okresie okołooperacyjnym [19], pacjentów w podstawowej opiece zdrowotnej [20, 21], pacjentów z przewlekłą niewydolnością serca [22], pacjentów z nadciśnieniem tętniczym [23], pacjenta ze stwardnieniem rozsianym [24] czy też pacjentów z białaczką $[25,26]$. Pojawiają się także pojedyncze opracowania ukazujące możliwości diagnozowania dla potrzeb opieki pielęgniarskiej stanu bólu ostrego przy użyciu systemu klasyfikacji diagnoz North American Nursing Diagnosis Association (NANDA) na przykładzie pacjentów po zabiegu wszczepienia endoprotezy stawu biodrowego [12]. Brakuje jednak w piśmiennictwie rodzimym pełnych wyników analiz dotyczących porównania opisu praktyki pielęgniarskiej opartej na systematyce klasyfikacji ICNP® oraz NANDA. Takie dowody można jednak odnaleźć w piśmiennictwie anglojęzycznym. Aby udowodnić przydatność obu klasyfikacji dla praktyki pielęgniarskiej, zostały one zastosowane do studium przypadku dotyczącego pensjonariusza mieszkającego w domu opieki [28]. Wyniki analizy wskazują, że ze względu na różną strukturę systematyki, zarówno NANDA, jak i ICNP®, mają swoje własne możliwości oraz ograniczenia w pokryciu indywidualnych potrzeb rezydenta opieki pielęgniarskiej. Te charakterystyczne potencjały i ograniczenia powinny być brane pod uwagę, szczególnie wtedy gdy jeden z systemów klasyfikacji będzie rozpatrywany jako projekt wdrożeniowy do rzeczywistej praktyki opieki pielęgniarskiej.

Wyniki analizy porównawczej systemów ICNP® i NANDA [9], w oparciu o opinię 20 ekspertów z różnych instytucji opieki, według ujednoliconych formularzy oceny klasyfikacji praktyki i ich użyteczności, definiują trzy ważne kryteria powyższych systemów, a także stanowisko ekspertów w powyższej kwestii, tj.:

- $\quad$ opisywanie bazy wiedzy i przedmiotu, za który jest odpowiedzialny zawód pielęgniarki (to kryterium w opinii ekspertów spełnione jest w systemie klasyfikacji zarówno ICNP®, jak i NANDA);

- lokalizowanie klas systemu w centralnej koncepcji opieki pielęgniarskiej (tylko klasyfikacja NANDA zbudowana jest w oparciu o wymiary koncepcyjnie tworzone w ujęciu klas o charakterze tradycji opieki i inspiracji wyrosłej z praktyki);

- $\quad$ szczegółowy opis diagnozy pielęgniarskiej obejmuje kryteria diagnostyczne i związaną z tym etiologię (ICNP® opisuje warunki diagnostyczne, NANDA w pełnym zakresie spełnia to kryterium).

Powyższa analiza ekspercka zgromadzonych w literaturze dowodów wskazuje, że system klasyfikacji NANDA spełnia większość szczegółowych kryteriów ujętych w strukturze wymagań koniecznych dla narzędzia, jakim jest klasyfikacja.

Niezależnie od wyników wielu opinii ostatecznym celem powinno być opracowanie jednego znormalizowanego słownika terminologii pielęgniarskiej dla wszystkich pielęgniarek. Stosowanie znormalizowanej terminologii nie jest czymś, co odbywa się tylko dlatego, że byłoby to przydatne dla innych członków zespołu terapeutyczno-opiekuńczego. Wykorzystanie standaryzowanego słownictwa ma daleko idące konsekwencje, które pomogą w realizacji opieki pielęgniarskiej oraz wykazaniu wartości pielęgniarstwa innym świadczeniodawcom. Korzyści znormalizowanej terminologii pielęgniarskiej obejmują bowiem: lepszą komunikację wśród pielęgniarek i innych pracowników służby zdrowia, zwiększenie widoczności interwencji pielęgniarskich, lepszą opiekę nad pacjentem, ulepszone zbieranie danych do oceny wyników opieki pielęgniarskiej, większą zgodność ze standardami opieki i wyższą ocenę kompetencji zawodowych pielęgniarstwa [29].

\section{Podsumowanie}

Uzyskane wyniki badań oraz wstępna analiza ilościowa i jakościowa podanych przez studentów argumentów użyteczności praktycznej systemów klasyfikacji ICNP® i NANDA sugeruje większą praktyczną użyteczność systemu klasyfikacyjnego NANDA dla działalności zawodowej pielęgniarek oraz jest zbieżna z naturą szeroko rozumianej opieki. W szczegółowym odniesieniu klasyfikacji NANDA i ICNP® do warunków polskiej praktyki pielęgniarskiej wymaga to dalszych badań i porównań możliwości oraz korzyści ich stosowania z uwzględnieniem etapu rozwoju, wypracowanych dotychczas rozwiązań praktycznych i tradycji rodzimego pielęgniarstwa. 


\section{Piśmiennictwo}

1. Kisilowska M. Międzynarodowa Klasyfikacja Praktyki Pielęgniarskiej - narzędzie zarządzania wiedzą w opiece zdrowotnej. EBiB 2005; 8: 69, http://www.ebib.pl/2005/69/kisilowska.php (data dostępu: 23.09.2016).

2. Kilańska D. Międzynarodowa Klasyfikacja Praktyki Pielęgniarskiej. Historia powstania. Mag Piel Położ. 2007; 4: 5, http://www.nursing.com.pl/ArchiwumMagazynu-PiP_Miedzynarodowa_Klasyfikacja_Praktyki_Pielegniarskiej_ Historia_powstania_61.html (data dostępu: 18.09.2016).

3. Kilańska D. Międzynarodowa Klasyfikacja Praktyki Pielęgniarskiej (ICNP®) - aktualny stan na świecie i etap prac przygotowawczych do wdrożenia w Polsce. Probl Piel. 2009; 17(3): 235-245.

4. Zarzycka D, Górajek-Jóźwik J. ICNP® w skali Polski, www.pzwl.pl/pdf.php?kid=632;10.08.2009 (data dostępu: 20.09.2016).

5. Hardiker NR. Developing standardized terminologies to support nursing practice. W: McGonigle D, Mastrian K (red). Nursing informatics and the foundation of knowledge. Wyd. 2. Boston: Jones and Bartlett Publishers LLC; 2011. 111-120.

6. American Nurses Association. Recognized terminologies and data element sets. 2006, http://www.nursingworld.org/ MainMenuCategories/ThePracticeofProfessionalNursing/ Health-IT/StandardizedNursingLanguage.html (data dostępu: 23.09.2016).

7. Udina MJ, Samartino MG, Calvo CM. Mapping the Diagnosis Axis of an Interface Terminology to the NANDA International Taxonomy. ISRN Nurs. 2012, https://www.ncbi. nlm.nih.gov/pmc/articles/PMC3399394/ (data dostępu: 23.10.2016).

8. Gordon M. Nursing nomenclature and classifi cation system development. OJIN. 1998; 3(2), http://www.nursingworld. org/MainMenuCategories/ANAMarketplace/ANAPeriodicals/ OJIN/TableofContents/Vol31998/No2Sept1998/NomenclatureandClassification.html (data dostępu: 23.10.2016).

9. Muller-Staub M, Lavin MA, Needham I, van Achterberg T. Meeting the criteria of a nursing diagnosis classification: evaluation of ICNP, ICF, NANDA and ZEFP. Int J Nurs Stud. 2007; 44(5): 702-713.

10. Ackley BJ, Ladwig GB (red.). Podręcznik diagnoz pielęgniarskich. Przewodnik planowania opieki opartej na dowodach naukowych. Zarzycka D, Ślusarska B (red. nauk. wyd. pol.). Warszawa: Wyd. Media House; 2011. 1-758.

11. Charzyńska-Gula M, Domżał-Drzewicka R, Ślusarska B. Forum Dyskusyjne Pielęgniarstwa w Lublinie. Alma Mater. 2014; 24(2/3): 82-85.

12. Ślusarska B, Fijałkowska B, Zarzycka D et al. Diagnozowanie dla potrzeb opieki pielęgniarskiej stanu bólu ostrego przy użyciu systemu klasyfikacji diagnoz North American Nursing Diagnosis Association (NANDA) w grupie pacjentów po zabiegu wszczepienia endoprotezy stawu biodrowego. Piel Chir Angiol. 2014; 8(4): 163-169.

13. Majda A, Kózka M. Diagnoza pielęgniarska w koncepcji NANDA. Pismo Małopolskiej OIPiP. 2015; 15: 13-17.

14. International Classification for Nursing Practice (ICNP®), http://www.icn.ch/what-we-do/international-classifi cationfor-nursing-practice-icnpr/ (data dostępu: 25.09.2016).

15. ICNP®MiędzynarodowaKlasyfikacjaPraktykiPielęgniarskiej wersja 1.0. Warszawa-Lublin: MakMed; 2009. 1-218.

16. Habel A, Cierzniakowska K, Grabowska H et al. Propozycja realizacji diagnoz pielęgniarskich z wykorzystaniem Międzynarodowej Klasyfikacji Praktyki Pielęgniarskiej u chorego operowanego z powodu przepukliny pachwinowej. Piel Chir Angiol. 2011; 4: 187-202.

17. Ikwanty K, Dobrowolska B. Wykorzystanie Międzynarodowej Klasyfikacji Praktyki Pielęgniarskiej (ICNP®) w diagno- zowaniu pacjenta Oddziału Intensywnej Opieki Medycznej. Piel XXI w. 2012; 1(38): 67-71.

18. Kozłowska E, Cierzniakowska K, Szewczyk MT. Wybrane diagnozy i działania pielęgniarskie u chorych z oparzeniem termicznym. Piel Chir Angiol. 2013; 1: 28-35.

19. Grabowska H, Grabowski W. Zakres interwencji pielęgniarskich w opiece nad chorym w okresie okołooperacyjnym z wykorzystaniem Międzynarodowej Klasyfikacji Praktyki Pielęgniarskiej. Probl Piel. 2014; 22(3): 385-389.

20. Kilańska D, Staszewska M, Urbanek $\mathrm{N}$ et al. Planowanie opieki według międzynarodowego standardu ICNP® w Podstawowej Opiece Zdrowotnej - studium przypadku. Probl Piel. 2014; 4(22): 539-545.

21. Kilańska D, Staszewska M, Urbanek $\mathrm{N}$ et al. Planowanie opieki według międzynarodowego standardu ICNP $\AA$ w Podstawowej Opiece Zdrowotnej - studium przypadku jednostki i rodziny. Część 2. Probl Piel. 2014; 4(22): 546-552.

22. Grabowska H. Mapowanie pojęć ICNP® w procesie pielęgnowania pacjentów z przewlekłą niewydolnością serca. Część 1 - problemy somatyczne chorego. Probl Piel. 2015; 23(1): 104-109.

23. Grabowska H, Grabowski W, Gaworska-Krzemińska A. Wykorzystanie ICNP® w opiece pielęgniarskiej nad pacjentem z nadciśnieniem tętniczym. Probl Piel. 2015; 22(1): 107-112.

24. Głowacka M, Kalinowska A. Shaping nursing professional skills with the use of the method of nursing process as well as diagnoses and nursing interventions according to ICNP oriented on the female patient with multiple sclerosis. JNNN. 2015; 4(2): 76-84.

25. Kilańska D, Niemiec L, Brosowska B. Studium przypadku dziecka z ostrą białaczką limfoblastyczną w czasie chemioterapii. Część I - zastosowanie ICNP®. Probl Piel. 2015; 1(23): 81-86.

26. Kilańska D, Niemiec L, Brosowska B. Studium przypadku dziecka z ostrą białaczką limfoblastyczną w czasie chemioterapii. Część II - zastosowanie ICNP®. Probl Piel. 2015; 1(23): 87-93.

27. Babska K. Międzynarodowa Klasyfikacja Praktyki Pielęgniarskiej - ICNP® - przyszłość polskiego pielęgniarstwa nefrologicznego. Forum Nefrol. 2015; 1: 49-54.

28. Schilder M. To represent needs of nursing care using nursing diagnoses: potentials and restrictions of the NANDA classification and ICNP. Pflege Z. 2005; 58(3): 2-8.

29. Furtado LG, Medeiros ACT, Nóbrega MML. Terminological subset of the international classifi cation for nursing practice: an integrative review. Braz J Nurs. 2013; 12(1): 178193, http://www.objnursing.uff.br/index.php/nursing/article/ view/3932.

Artykuł przyjęty do redakcji: 15.09.2016

Artykuł przyjęty do publikacji: 16.02.2017

Źródło finansowania: Praca nie jest finansowana z żadnego źródła. Konflikt interesów: Autorzy deklarują brak konfliktu interesów.
Adres do korespondencji:
Barbara Ślusarska
ul. Stanisława Staszica 4/129
20-081 Lublin
tel.: 814486812
e-mail: barbaraslusarska@umlub.pl
Zakład Medycyny Rodzinnej i Pielęgniarstwa Środowiskowego
Uniwersytet Medyczny w Lublinie 